\title{
Reduced Rate of DNA Replication Fork Movement in
}

\section{Megaloblastic Anemia}

\author{
R. Gitendra Wickremasinghe and A. Victor Hoffbrand, Department of \\ Haematology, Royal Free Hospital, London, England NW3 2QG
}

A B S T R A C T Chromatography on benzoylated naphthoylated DEAE-cellulose has been used to fractionate fully double-stranded from partially single-stranded DNA molecules. DNA was extracted from phytohemagglutinin-stimulated lymphocytes from patients with megaloblastic anemia resulting from vitamin B12 or folate deficiency after pulse-labeling the cells with $\left[{ }^{3} \mathrm{H}\right]$ thymidine for $5 \mathrm{~min}$ and chasing in unlabeled medium for $24 \mathrm{~h}$. No gross accumulation of partially single-stranded material was observed in the DNA of these cells when compared with DNA from similarly labeled control cells obtained by the addition of 5formyl tetrahydrofolic acid to the culture medium. When DNA from lymphocytes labeled with a 5-min pulse of $\left[{ }^{3} \mathrm{H}\right]$ thymidine and sheared to fragments of an average length of $18 \mu \mathrm{m}$ was chromatographed on benzoylated naphthoylated DEAE-cellulose, $\sim 80 \%$ of the label was recovered in the partially single-stranded fraction. After chasing in unlabeled medium the label was progressively transferred to the double-stranded fraction over a period of $2-3 \mathrm{~h}$. The rate of transfer was slower in megaloblastic lymphocytes than in controls.

The difference in rate suggested a slower rate of replication fork movement in megaloblastic lymphocytes and so the density shift technique of Painter and Schaeffer (J. Mol. Biol. 45: 467-479, 1969) was used to measure the fork rate directly. $\left[{ }^{3} \mathrm{H}\right]$ Deoxycytidine was used as the labeled nucleoside to avoid possible complications arising from $\left[{ }^{3} \mathrm{H}\right]$ thymidine labeling of megaloblastic cells. Investigations on the lymphocytes from four patients showed that the replication fork rate in vitamin-treated control lmphocytes was about $1 \mu \mathrm{m} / \mathrm{min}$. The fork rates in the corresponding untreated cells were invariably lower and rates ranging from 40 to $92 \%$ of those of controls were observed.

Normal lymphocytes treated with the deoxynucleotide pool-depleting drugs methotrexate or hydroxyurea displayed defects in DNA synthesis similar to those of untreated megaloblastic lymphocytes. We propose

Received for publication 19 March 1979 and in revised form 30 July 1979. that the delayed DNA replication fork movement in cells of patients with megaloblastic anemia results from impaired biosynthesis of DNA precursors.

\section{INTRODUCTION}

Duplication of the genomes of eukaryotes occurs via the activity of replicating unils (replicons) of $15-100 \mu \mathrm{m}$ in length, arranged in tandem along the chromosomal DNA strands $(1,2)$. Within each replicon two replication forks initiate synthesis at a single origin and proceed in opposite directions. Termination of DNA synthesis involves the joining together of DNA strands newly synthesized within adjacent replicons. At least one of the daughter strands synthesized at each replication fork must be made discontinuously in the form of short fragments of $\sim 200$ nucleotides (Okazaki pieces) (3-6). There is evidence that these pieces are synthesized by extension of short ( $\sim 10$ nucleotide) RNA primers (7-9). The RNA primers are then excised, the gaps between the Okazaki pieces filled, and the fragments joined to yield longer DNA molecules (10).

Hoffbrand et al. (11) have summarized evidence indicating that the common feature of megaloblastic anemias of varying etiology is a defect in DNA synthesis resulting from impaired biosynthesis of DNA precursors. They have suggested that the cellular abnormalities in this syndrome may be explained by the selective inhibition of the gap-filling step, and/or joining of Okazaki pieces, resulting in DNA with persistent single-stranded regions. Indeed, a markedly reduced rate of joining of Okazaki pieces has been observed in cells treated with hydroxyurea $(12-14)$ or fluorodeoxyuridine $(15,16)$. Both these drugs interfere with deoxyribonucleotide biosynthesis and are also known to cause megaloblastic anemia in vivo.

Previous work has shown that phytohemagglutinin (PHA)'-stimulated lymphocytes from patients with

\footnotetext{
${ }^{1}$ Abbreviations used in this paper: BND-cellulose, benzoylated naphthoylated DEAE-cellulose; BUdR, bromodeoxyuridine; CdR, deoxycytidine; FUdR, fluorodeoxyuridine; PBS, phosphate-buffered saline; PHA, phytohemagglutinin; TdR, deoxythymidine.
} 
megaloblastic anemia display similar morphological, chromosomal, and biochemical abnormalities to those of bone marrow cells $(17,18)$. In vitro treatment of these cells with folinic acid (5-formyl tetrahydrofolic acid) corrects these defects. In a previous study (19) we have used this system to show that the maturation of DNA strands synthesized within individual replicons to yield chromosome-sized strands is delayed in megaloblastic anemia.

In the present study chromatography on benzoylated naphthoylated DEAE (BND)-cellulose has been used to separate fully double-stranded from partially singlestranded DNA (20). We have used this technique to show that the transfer of pulse label from the partially single-stranded to the double-stranded DNA fraction is slower in untreated megaloblastic lymphocytes than in control cells. Because this data suggested that the rate of replication fork movement might be reduced in megaloblastic anemia, direct measurements of this parameter were undertaken using an adaptation of the density shift technique of Painter and Schaeffer (21). This method involves labeling of cells with a ${ }^{3} \mathrm{H}$ labeled deoxyribonucleoside for a brief period (5-30 min) followed by a chase $(2-3 \mathrm{~h})$ in the presence of the thymidine analogue bromodeoxyuridine (BUdR). The DNA from the labeled cells is extracted, sheared to fragments of a known average size, and centrifuged to equilibrium in a neutral $\mathrm{CsCl}$ density gradient. DNA labeled with BUdR has a greater density in $\mathrm{CsCl}$ than does normal DNA. If the DNA is sheared to fragments that are small compared with the length of the ${ }^{3} \mathrm{H}$ labeled segment, little of the ${ }^{3} \mathrm{H}$ label will be covalently associated with BUdR-labeled DNA and hence band at densities greater than that of normal DNA. If, on the other hand, the DNA fragments are large compared with the length of the labeled segment, more of the ${ }^{3} \mathrm{H}$ label will be associated with the denser BUdRlabeled DNA.

Equations derived by A. D. Hershey (21) enable the length of the ${ }^{3} \mathrm{H}$-labeled segment to be computed if the average size of the DNA molecules analyzed and the fraction of ${ }^{3} \mathrm{H}$ label banding at densities greater than that of normal DNA are known (see Methods). Our studies on lymphocytes from four patients with megaloblastic anemia showed clearly that the rate of replication fork movement was slower in these cells than in normal lymphocytes or in controls derived by the addition of folinic acid to cultures of megaloblastic lymphocytes. A similar defect could be demonstrated by this technique in normal lymphocytes treated with methotrexate or hydroxyurea.

\section{METHODS}

Reagents. [5- $\left.{ }^{3} \mathrm{H}\right]$ Deoxycytidine (CdR, $\left.20 \mathrm{Ci} / \mathrm{mmol}\right),[$ methyl$\left.{ }^{3} \mathrm{H}\right]$ thymidine $(40 \mathrm{Ci} / \mathrm{mmol})$ and $\left[{ }^{14} \mathrm{C}\right]$ thymidine $(60 \mathrm{mCi} / \mathrm{mmol})$ were from The Radiochemical Centre, Amersham, England.
CdR, BUdR, fluorodexyuridine (FUdR), pancreatic ribonuclease, pronase, and Neurospora crassa single-strand-specific nuclease were from Sigma Chemical Co., St. Louis, Mo. BND-cellulose was purchased from Boehringer-Mannheim, Mannheim, West Germany. Methotrexate was a gift from Lederle Laboratories, Pearl River, N. Y. Medium TC 199 and PHA were from Wellcome Research Laboratories, Beckenham, Kent, England. All other reagents were of analytical grade.

Patients. Hematological data relating to the patients studied are summarized in Table I. All patients had florid megaloblastic bone marrow appearances and ample bone marrow iron.

Lymphocyte culture. Lymphocytes were prepared from 30 to $50 \mathrm{ml}$ of heparinized venous blood from patients with megaloblastic anemia or from healthy volunteers. Lymphocytes were purified by sedimentation on a Triosill-Ficol gradient (Nyegaard and Co., Oslo, Norway) (22). Cells from patients were cultured at $10^{6} \mathrm{cells} / \mathrm{ml}$ in TC 199 without thymine or folic acid, and supplemented with $20 \%$ autologous serum that had been dialyzed overnight against phosphate-buffered saline (PBS). Dialysis was used to remove folic acid and thymidine from serum. Controls were obtained by the addition of $30 \mu \mathrm{g} / \mathrm{ml}$ of folinic acid (calcium leucovorin, Lederle Laboratories) to half of the cultures. Normal lymphocytes for experiments with methotrexate or hydroxyurea were cultured in complete TC 199 supplemented with $20 \%$ autologous serum. All cultures were stimulated by the addition of $10 \mu \mathrm{l} / \mathrm{ml} \mathrm{PHA}$ and used at $72 \mathrm{~h}$ after initiation.

Labeling of marker DNA. [U-14C]DNA for use as a marker for BND-cellulose chromatography was prepared by labeling a 3-ml lymphocyte culture with $2.5 \mu \mathrm{Ci}\left[{ }^{14} \mathrm{C}\right]$ thymidine for $18 \mathrm{~h}$, washing the cells and incubating for a further $6 \mathrm{~h}$ in unlabeled medium. Normal density $\left[{ }^{14} \mathrm{C}\right] \mathrm{DNA}$ for use as a marker on $\mathrm{CsCl}$ gradients was prepared by incubating normal lymphocytes with $0.16 \mu \mathrm{Ci} / \mathrm{ml}\left[{ }^{14} \mathrm{C}\right]$ deoxythymidine (TdR) for $18 \mathrm{~h}$. Normal density $\left[{ }^{3} \mathrm{H}\right] \mathrm{DNA}$ was prepared from lymphocytes labeled for $18 \mathrm{~h}$ with $3 \mu \mathrm{Ci} / \mathrm{ml}\left[{ }^{3} \mathrm{H}\right] \mathrm{TdR}$. [ $\left.{ }^{14} \mathrm{C}\right] \mathrm{DNA}$ substituted with BUdR was extracted from lymphocytes incubated for $18 \mathrm{~h}$ with $0.16 \mu \mathrm{Ci} / \mathrm{ml}\left[{ }^{14} \mathrm{C}\right] \mathrm{TdR}$ in the presence of $20 \mu \mathrm{M}$ BUdR and $1 \mu . \mathrm{M}$ FUdR. DNA was purified from all labeled cells as described below.

Analysis of pulse-labeled and chased DNA by BNDcellulose column chromatography. Lymphocytes were concentrated to $\sim 30 \times 10^{6} / \mathrm{ml}$ and labeled for $5 \mathrm{~min}$ at $37^{\circ} \mathrm{C}$ with $200 \mu \mathrm{Ci} / \mathrm{ml}\left[{ }^{3} \mathrm{H}\right]$ thymidine. They were then diluted with $10 \mathrm{vol}$ of medium without serum and a $1-\mathrm{ml}$ sample taken immediately into ethanol at $-20^{\circ} \mathrm{C}$. The remaining cells were collected by low-speed centrifugation, resuspended in fresh medium, and incubation continued at $37^{\circ} \mathrm{C}$. Further samples were taken into cold ethanol at suitable intervals. In all experiments involving megaloblastic lymphocytes that had been treated in vitro with folinic acid, this vitamin was also present at the same concentration in the chase medium. When normal cells treated with methotrexate or hydroxyurea were being studied, the cells were preincubated with the drug for $1 \mathrm{~h}$ before labeling, and appropriate concentrations of the drug were present in the chase media.

Labeled cells were centrifuged from the ethanol, washed twice with ice-cold PBS, and lysed in $1 \%$ sodium dodecyl sulfate, $1 \mathrm{mM}$ EDTA, in PBS. A concentrated solution of pronase (previously heated at $37^{\circ} \mathrm{C}$ for $30 \mathrm{~min}$ ) was added to give a final concentration of $500 \mu \mathrm{g} / \mathrm{ml}$ and the solution incubated at $37^{\circ} \mathrm{C}$ for $3 \mathrm{~h}$. NaCl was then added to a concentration of $1 \mathrm{M}$ and the samples extracted three times with equal volumes of phenol containing $0.1 \%$ (wt/vol) 8-hydroxyquinoline. The phenol was carefully pipetted from under the aqueous layer after each extraction so that any material at 
TABLE I

Hematological Data

\begin{tabular}{lccccccl}
\hline Patient & Age & Sex & Hemoglobin & $\begin{array}{c}\text { Mean cell } \\
\text { volume }\end{array}$ & Serum folate* & Serum vitamin $\mathrm{B}_{\mathbf{1 2}} \mathrm{f}$ & \multicolumn{1}{c}{ Diagnosis } \\
\hline & $y r$ & & $g / d l$ & $f l$ & $\mu g /$ liter & $n g /$ liter & \\
A.B. & 70 & $\mathrm{M}$ & 6.7 & 110 & 9.1 & 120 & Pernicious anemia \\
A.S. & 54 & $\mathrm{~F}$ & 7.9 & 113 & 2.8 & 220 & Nutritional folate deficiency \\
B.T. & 51 & $\mathrm{M}$ & 7.4 & 127 & 7.2 & 90 & Pernicious anemia \\
A.M. & 78 & $\mathrm{~F}$ & 4.4 & 112 & 4.9 & 100 & Pernicious anemia \\
B.McI & 56 & $\mathrm{~F}$ & 5.8 & 131 & 1.0 & 60 & Mixed deficiency \\
M.P. & 61 & $\mathrm{~F}$ & 5.8 & 125 & 4.2 & 120 & Pernicious anemia \\
G.M. & 64 & $\mathrm{M}$ & 5.1 & 130 & 2.0 & 250 & Nutritional folate deficiency \\
\hline
\end{tabular}

* Normal range 3-20 $\mu \mathrm{g} /$ liter.

\$ Normal range 160 -925 ng/liter.

the interphase was retained with the aqueous layer. In this way loss of pulse label at the interphase was prevented (23). DNA was precipitated from the aqueous phase by the addition of $2.5 \mathrm{vol}$ of ethanol and storage at $-70^{\circ} \mathrm{C}$ overnight. DNA was collected by centrifugation, washed twice with cold ethanol, and dissolved in $0.3 \mathrm{M} \mathrm{NaCl}, 1 \mathrm{mM}$ EDTA, $10 \mathrm{mM}$ Tris- $\mathrm{HCl}, \mathrm{pH} 7.8$.

The DNA was sheared by passage through a 19-gauge syringe needle to yield pieces with an average size of $\sim 18 \mu \mathrm{m}$ as determined by neutral sucrose gradient analysis as described below. The sheared DNA was then analyzed by BND-cellulose chromatography. All buffers contained $10 \mathrm{mM}$ Tris- $\mathrm{HCl}, \mathrm{pH}$ 7.8 , and $1 \mathrm{mM}$ EDTA in addition to the stated components. BND-cellulose was equilibrated with an excess of $0.3 \mathrm{M} \mathrm{NaCl}$, packed into plastic columns (bed size $8 \times 30 \mathrm{~mm}$ ), and washed again with the same buffer. DNA samples $(<10 \mu \mathrm{g}$ DNA) were loaded onto the columns and washed with $0.3 \mathrm{M} \mathrm{NaCl}$. Double-stranded DNA was eluted with $6 \mathrm{ml}$ of $1 \mathrm{M} \mathrm{NaCl}$ and partially single-stranded material by successive elution with $6 \mathrm{ml}$ of $1 \mathrm{M} \mathrm{NaCl}, 1.75 \%$ caffeine followed by $6 \mathrm{ml}$ of $6 \mathrm{M}$ guanidinium hydrochloride. A flow rate of $0.8 \mathrm{ml} / \mathrm{min}$ was maintained and $1.25 \mathrm{ml}$ fractions collected. 1-ml aliquots were counted in $10 \mathrm{ml}$ of toluene-based scintillation fluid containing 33\% (vol/vol) Triton X-100 (Rohm and Haas Co., Philadelphia, $\mathrm{Pa}$.). Where necessary, correction was made for overlap of ${ }^{14} \mathrm{C}$ counts into the ${ }^{3} \mathrm{H}$ channel.

Recoveries were $>80 \%$. Results obtained using BNDcellulose chromatography were highly reproducible for a given sample. In a series of five consecutive separations of a sample of ${ }^{14} \mathrm{C}$-labeled bulk DNA (sheared to $18 \mu \mathrm{m}$ ) the proportions of counts eluted by $1 \mathrm{M} \mathrm{NaCl}$ were 79, 76, 77, 76, and $78 \%$ of the total. Sonication for 2 min did not significantly alter the proportion of bulk DNA behaving as double-stranded material. On the other hand, only $6 \%$ of a denatured DNA preparation was eluted by $1 \mathrm{M} \mathrm{NaCl}$.

Treatment of DNA with $N$. crassa endonuclease. Pulselabeled DNA $(2 \mu \mathrm{g})$ was treated with $2 \mathrm{U} / \mathrm{ml}$ of $N$. crassa endonuclease (24) in $50 \mathrm{mM}$ Tris- $\mathrm{HCl}, \mathrm{pH} 7.8,20 \mathrm{mM} \mathrm{MgCl}$, $10 \mathrm{mM}$ 2-mercaptoethanol for $30 \mathrm{~min}$ at $37^{\circ} \mathrm{C}$. Reactions were terminated by the addition of EDTA to $25 \mathrm{mM}$. Samples were dialyzed against two changes of BND-cellulose loading buffer. Control samples were treated as above except that incubation was carried out in the absence of nuclease.

Density shift procedure for the estimation of the rate of replication fork movement. Approximately $6 \times 10^{6}$ lymphocytes in $0.2 \mathrm{ml}$ medium were labeled with $100 \mu \mathrm{Ci}$ freezedried $\left[{ }^{3} \mathrm{H}\right] \mathrm{CdR}$ for $15 \mathrm{~min}$. (In the experiment of Figs. 3 and 4, the labeling time was varied as indicated.) The labeling was stopped and the chase commenced by the addition of $5 \mathrm{ml}$ fresh medium containing $100 \mu \mathrm{M} \mathrm{CdR}, 20 \mu \mathrm{M} \mathrm{BUdR}$, and $1 \mu \mathrm{M}$ FUdR. The cells were collected by centrifugation and resuspended in $5 \mathrm{ml}$ of the same medium containing only $10 \mu \mathrm{M} \mathrm{CdR}$ and the cells incubated for another $2 \mathrm{~h}$. The culture was then diluted with an equal volume of ice-cold PBS, and the cells collected by centrifugation. After two additional washes with cold PBS, the cells were lysed and DNA extracted as described above, except that a 1-h incubation with $50 \mu \mathrm{g} / \mathrm{ml}$ of RNase preceded the pronase digestion. The exposure of BUdR-labeled DNA to light was minimized to avoid strand scission. The presence of FUdR, a potent inhibitor of thymidylate synthetase, permitted maximal substitution of BUdR in place of TdR.

The $\left[{ }^{3} \mathrm{H}\right]$ CdR-BUdR labeled DNA was mixed with a suitable amount $\left(0.02-0.1\right.$ time the total ${ }^{3} \mathrm{H}$ counts per minute) of normal density ${ }^{14} \mathrm{C}$ marker DNA and sheared by three passages through either a 21- or 25-gauge syringe needle. The sizes of the fragments produced were determined by neutral sucrose density gradient sedimentation described below. $0.2 \mathrm{ml}$ of each mixture was placed in a siliconized $10-\mathrm{ml}$ polyallomer centrifuge tube. To each tube, $1.65 \mathrm{ml}$ of a solution of $\mathrm{CsCl}$ (refractive index 1.4091) was added, and the total volume adjusted to $5 \mathrm{ml}$ with a $\mathrm{CsCl}$ solution of refractive index 1.4010 . All $\mathrm{CsCl}$ solutions contained $10 \mathrm{mM}$ Tris- $\mathrm{HCl}, \mathrm{pH} 7.8,10 \mathrm{mM} \mathrm{NaCl}$, and $1 \mathrm{mM}$ EDTA. The refractive index of the final mixture was 1.4010 , corresponding to a $d$ of $1.715 \mathrm{~g} / \mathrm{ml}$. The tubes were then filled with liquid paraffin and centrifuged at $100,000 \mathrm{~g}$ for $38-42 \mathrm{~h}$ in the 10 $\times 10-\mathrm{ml}$ rotor of the MSE Superspeed 75 ultracentrifuge (MSE Scientific Instruments, Manor Royal, Crawley, Sussex, England). $0.2-\mathrm{ml}$ fractions were collected from the tube bottoms and 0.1-ml aliquots precipitated on filter disks (25). The dried disks were counted in $10 \mathrm{ml}$ of a toluene-based scintillant in a LKB-Wallac L 1210 scintillation counter (Laboratorie och Kemikaliska Productor, Stockholm, Sweden). Correction was made for the overlap of ${ }^{14} \mathrm{C}$ into the ${ }^{3} \mathrm{H}$ channel. The peak of ${ }^{14} \mathrm{C}$ label was normalized to the ${ }^{3} \mathrm{H}$ counts per minute by equating the counts in the ${ }^{14} \mathrm{C}$ peak fraction to the ${ }^{3} \mathrm{H}$ counts per minute in the same fraction, and adjusting the ${ }^{14} \mathrm{C}$ counts per minute of all other fractions by the same ratio (21). The fraction of ${ }^{3} \mathrm{H}$ counts per minute banding at densities greater than that of normal DNA was then computed by subtracting the adjusted ${ }^{14} \mathrm{C}$ counts per minute from the total ${ }^{3} \mathrm{H}$ counts per minute and dividing the result by the total number of ${ }^{3} \mathrm{H}$ counts per minute recovered.

The length of the ${ }^{3} \mathrm{H}$-labeled DNA segment was calculated using the equations derived by Hershey (21). If the average 
length of the DNA molecules analyzed was B (in microns) and $F_{H}$ was the fraction of ${ }^{3} \mathrm{H}$ counts per minute banding at densities greater than that of normal DNA, the length of the labeled DNA segment in microns $\left(\mathrm{L}_{\mathrm{c}}\right)$ is given by

$$
L_{c}=\frac{B}{2 F_{H}} \text { if } L_{c} \geqslant B
$$

or

$$
\mathrm{L}_{\mathrm{c}}=2 \mathrm{~B}\left(1-\mathrm{F}_{\mathrm{H}}\right) \text { if } \mathrm{L}_{\mathrm{c}} \leqslant \mathrm{B} \text {. }
$$

In practice, the equations were found to give roughly similar results for a given set of data. Eq. 1 was used to determine roughly the relative magnitudes of $L_{c}$ and $B$, and a second calculation was carried out using Eq. 2, if necessary. Correction of $F_{H}$ values as carried out by Painter and Schaeffer (21) was found to be unnecessary, because the chase protocol employed by us prevented incorporation of radiolabel during the BUdRlabeling period. In preliminary experiments, $\mathrm{CsCl}$ gradient centrifugation of DNA labeled by the above protocol and sheared to a low molecular weight by sonication was carried out. Under these conditions, none of the radiolabel banded at a density greater than that of normal density DNA, confirming that no significant amount of radiolabel was incorporated into the BUdR-labeled DNA segment.

Neutral sucrose density gradient sedimentation The sizes of DNA fragments analyzed in each $\mathrm{CsCl}$ gradient were estimated by sedimentation through $5-20 \%$ sucrose gradients containing $10 \mathrm{mM}$ Tris- $\mathrm{HCl}, \mathrm{pH} 7.8,1 \mathrm{mM}$ EDTA, and $1 \mathrm{M}$ $\mathrm{NaCl}$. About $1 \mu \mathrm{g}$ of DNA was loaded on each 5-ml gradient, which was then centrifuged at $35,000 \mathrm{~g}$ for $16 \mathrm{~h}$ at $16^{\circ} \mathrm{C}$ in the $6 \times 5.5-\mathrm{ml}$ rotor of the MSE Superspeed 75 Ultracentrifuge. $0.2-\mathrm{ml}$ fractions were collected from the bottom of each tube and aliquots processed for scintillation counting as described above. Sucrose concentrations in selected fractions were determined by refractometry. The $s_{20, x}$ values were computed by the calculation method of Funding and Steensgaard (26). This procedure permits the calculation of sedimentation coefficients at any point on a gradient of any shape without reference to markers. The accuracy of the calculation method was checked in preliminary experiments using $\left[{ }^{3} \mathrm{H}\right]$ adenovirus DNA (31 S). Molecular weights were derived from $s_{20, u}$ values by the method of Studier (27), and lengths of DNA molecules calculated assuming that $1 \mu \mathrm{m}$ of double-helical DNA has a molecular weight of $2 \times 10^{6}$.

\section{RESULTS}

Quantitation of partially single-stranded DNA in megaloblastic lymphocytes. Initially, BND-cellulose chromatography was used to determine whether the DNA of untreated PHA-stimulated lymphocytes from patients with megaloblastic anemia contained a higher content of single-stranded regions than vitamin-treated controls. Lymphocytes from patient A.B. were pulselabeled for $5 \mathrm{~min}$ with $\left[{ }^{3} \mathrm{H}\right]$ thymidine, washed, and incubated in unlabeled medium for $24 \mathrm{~h}$ before extraction of DNA. The BND-cellulose elution profiles of the DNA from untreated and vitamin-treated lymphocytes were virtually identical (Fig. 1). Similarly, labeled DNA of lymphocytes from a normal donor also showed a similar elution pattern, with $\sim 75 \%$ of the label eluted by $1 \mathrm{M} \mathrm{NaCl}$ and presumably double-stranded (data not shown). A similar experiment using cells from

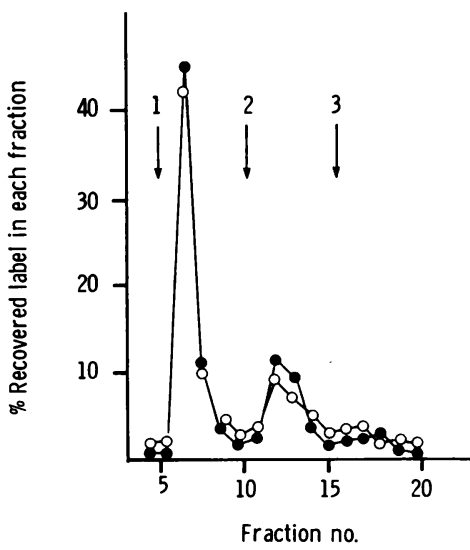

FIgURE 1 BND-cellulose chromatography of DNA labeled for 5 min with $\left[{ }^{3} \mathrm{H}\right]$ thymidine and chased for $24 \mathrm{~h}, 13,800$ cpm of untreated cell DNA; $0,5,300 \mathrm{cpm}$ of DNA from vitamin-treated lymphocytes from patient A.B. were run on parallel columns. 1,2 , and 3 refer to elution by $1 \mathrm{M} \mathrm{NaCl}$, $1.75 \%$ caffeine $+1 \mathrm{M} \mathrm{NaCl}$, and $6 \mathrm{M}$ guanidinium hydrochloride, respectively.

patient A.S. gave almost identical results (data not shown). For comparison, analogous experiments were carried out using normal lymphocytes treated with $20 \mu \mathrm{M}$ methotrexate or $0.5 \mathrm{mM}$ hydroxyurea. In both experiments no increase was observed in partially single-stranded DNA in cells treated with either drug compared with control cells (data not shown).

Comparison of the rates of conversion of pulselabeled DNA to a fully double-stranded form in control and megaloblastic lymphocytes. In the next series of experiments lymphocytes were labeled for $5 \mathrm{~min}$ with $\left[{ }^{3} \mathrm{H}\right]$ thymidine and chased for $3-5 \mathrm{~h}$. DNA purified from the cells immediately after the pulse and at various times during the chase was analyzed on BND-cellulose columns, and the percentage of recovered label eluting in the double-stranded and partially single-stranded fractions was calculated. After the 5 -min pulse, $\sim 80 \%$ of the label was recovered in the partially single-stranded fraction (Fig. 2A-D). In vitamin-treated megaloblastic lymphocytes (Fig. 2A) and in normal lymphocytes in the absence of drugs (Fig. 2B-D), the proportion of label in this fraction decreased, with a concomitant increase of label in the double-stranded fraction. After $1-2 \mathrm{~h}$ of chase, the proportion of label in partially single-stranded DNA in control cells became equal to that in the uniformly labeled $\left[{ }^{14} \mathrm{C}\right] \mathrm{DNA}$ included in each column run (75-80\% fully double-stranded). In contrast, the rate of loss of pulse label from partially single-stranded DNA was substantially slower in untreated megaloblastic lymphocytes (Fig. 2A). Experiments carried out using lymphocytes from two further megaloblastic anemia patients gave similar results (data not shown). A delay was also observed in cells treated with $10 \mu \mathrm{M}$ methotrex- 


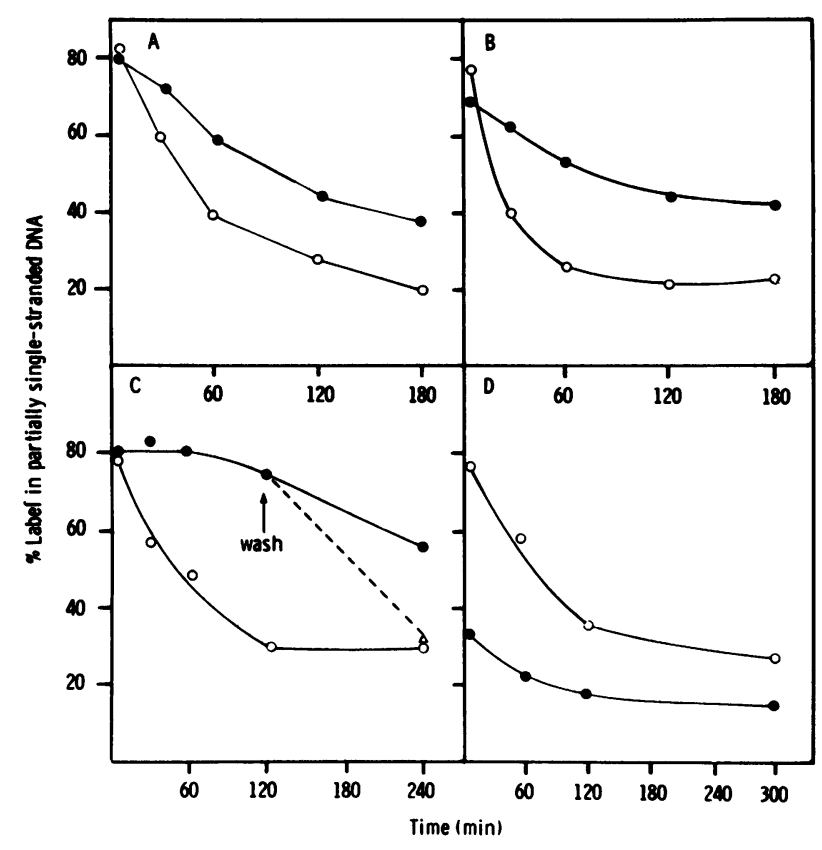

FIgure 2 Time-dependent transfer of 5-min $\left[{ }^{3} \mathrm{H}\right] \mathrm{TdR}$ pulse label to the double-stranded DNA fraction during chase. Figures in brackets give the approximate counts per minute loaded onto each column in each series. (A) Cells from patient B.T.: O, untreated $(54,000 \mathrm{cpm}), \bigcirc$, vitamin-treated $(35,000 \mathrm{cpm})$. (B) , normal cells treated with $10 \mu \mathrm{M}$ methotrexate $(175,000$ cpm), $\bigcirc$ control without drug $(96,000 \mathrm{cpm})$. (C) $\bigcirc$, normal cells treated with $0.2 \mathrm{mM}$ hydroxyurea $(8,800 \mathrm{cpm}), O$ control without drug $(42,000 \mathrm{cpm}$. (D) Normal cells: $O$, DNA sheared through 19-gauge needle $(22,000 \mathrm{cpm}), 0$, DNA sheared by sonication $(22,000 \mathrm{cpm})$.

ate (Fig. 2B) and a more pronounced lag was observed in cells treated with $0.2 \mathrm{mM}$ hydroxyurea (Fig. 2C). Inhibition by hydroxyurea is reversible (28) and, as expected, removal of the drug by washing the cells at $2 \mathrm{~h}$ of chase permitted a rapid conversion of the pulse label to the fully double-stranded form (Fig. 2C), indicating that the accumulated intermediates were structurally normal. In none of the experiments of Fig. 2 was a total block in the transfer of pulse label to the double-stranded DNA fraction observed. Lymphocytes from a normal donor cultured in the absence of added folinic acid gave a pulse-chase profile indistinguishable from a parallel culture to which the vitamin was added (data not shown). This experiment indicates that the observed lag in transfer of pulse label to the $1 \mathrm{M} \mathrm{NaCl}$ fraction in untreated megaloblastic cells is a feature of the disease and not an artefact resulting from the culture conditions.

To obtain a clearer understanding of the nature of the pulse-labeled material behaving as partially singlestranded DNA, the following experiment was carried out. 45,000 cpm of pulse-labeled DNA was incubated with or without $2 \mathrm{U} / \mathrm{ml}$ of the single-strand-specific endonuclease from $N$. crassa for $30 \mathrm{~min}$ and then chromatographed on BND-cellulose. The proportion of label eluting in the caffeine and guanidinium hydrochloride (partially single-stranded) fractions was substantially reduced by nuclease treatment, with a concomitant absolute increase of label recovered in the $1 \mathrm{M} \mathrm{NaCl}$ eluate. The sample incubated in the absence of nuclease contained $78 \%$ of pulse-labeled material eluting in the partially single-stranded DNA fractions. Incubation with nuclease reduced the partially singlestranded label to $28 \%$ of the recovered counts. In this experiment there was no loss of acid-precipitable label during the incubation, suggesting that the newly formed DNA consisted of labeled fragments annealed to the template strand in such a way that singlestranded stretches of unlabeled template DNA occurred between the nascent fragments. Treatment with the single-strand-specific nuclease would then be expected to degrade the single-stranded regions in the template strand, resulting in the release of the pulselabeled DNA in a fully double-stranded form (29 and $30)$. Incubation with higher concentrations of nuclease or for longer times led to more complete conversion to the double-stranded form, but some loss of label also occurred, presumably a result of contamination of the nuclease preparation with an activity that attacked double-stranded DNA.

The DNA fragments analyzed in the above experiments were of an average size, $18 \mu \mathrm{m}$, measured by neutral sucrose gradient centrifugation. It also seemed likely that the elution of pulse label in the partially single-stranded fraction before chasing was a result of the presence of stretches of single-stranded DNA at the replication fork. The transfer of pulse label to the fully double-stranded fraction that occurred over several hours of chasing appeared to reflect the rate of replication fork movement, because the fork must have moved out of a DNA fragment containing pulse label before the label could elute as fully doublestranded DNA. When the DNA samples labeled by the procedure used in Fig. 2A-C had been sonicated before chromatography, the bulk of the label appeared in double-stranded DNA even immediately after the pulse (Fig. 2D). Fragmentation of the DNA also reduced the time-dependent transfer of pulse label to the $1-\mathrm{M} \mathrm{NaCl}$ eluate. Because sonication detaches much of the label from the DNA containing the fork, this experiment supports the idea that the results of Fig. 2A-C reflect the reduced rate of replication fork movement in untreated megaloblastic lymphocytes and in lymphocytes treated with hydroxyurea or methotrexate.

Validation of the method for calculation of the rate of replication fork movement. To establish a suitable procedure for the direct measurement of the rate of fork movement, normal lymphocytes were labeled with $\left[{ }^{3} \mathrm{H}\right] \mathrm{CdR}$ for increasing lengths of time (5-40 min) and 


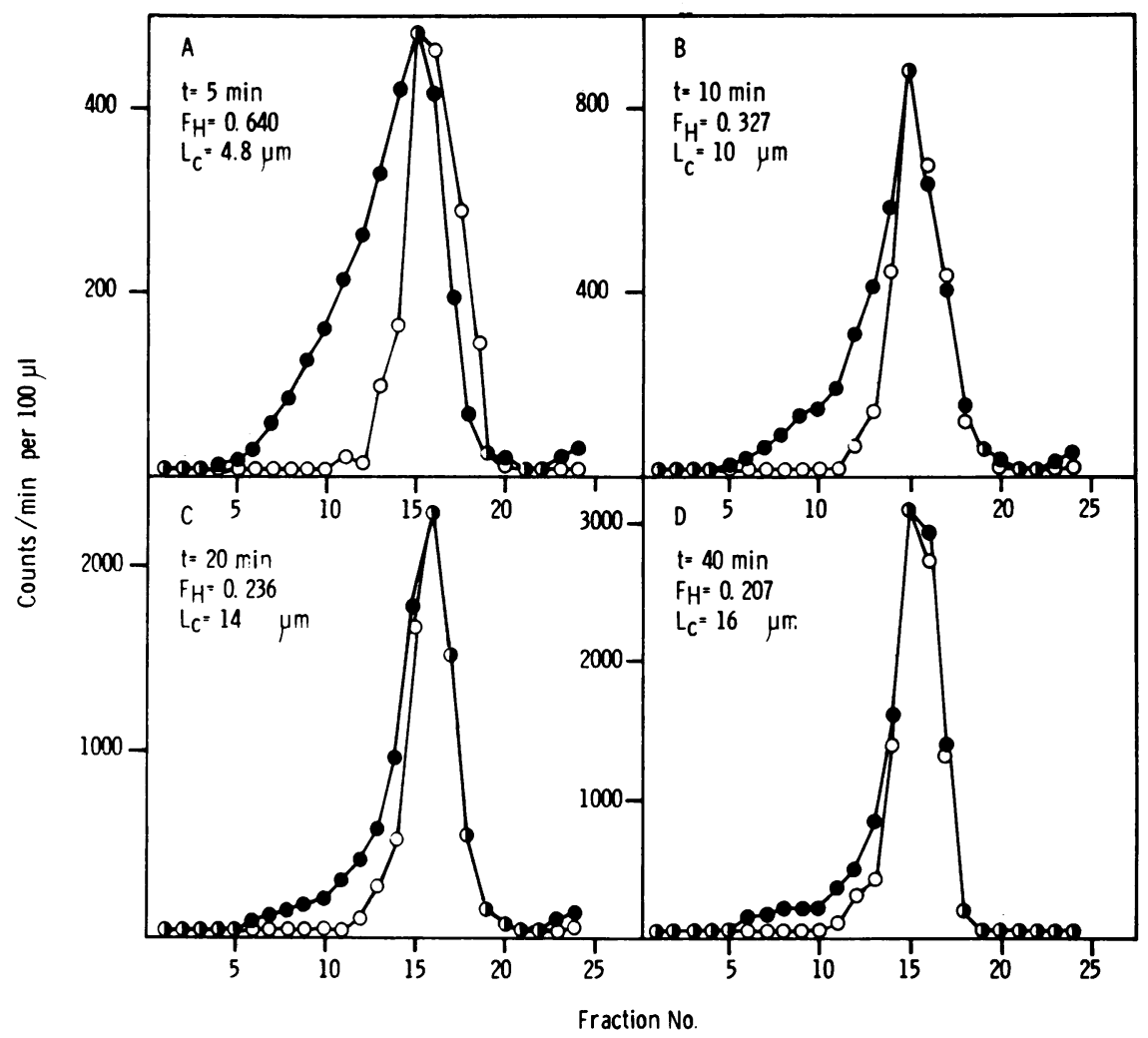

FIgURE $3 \mathrm{CsCl}$ density gradient profiles from normal lymphocytes labeled for increasing times and chased in the presence of BUdR for $2 \mathrm{~h}$. Times of labeling with $\left[{ }^{3} \mathrm{H}\right] \mathrm{CdR},(\mathrm{t})$; the fraction of ${ }^{3} \mathrm{H}$ label in material of greater than normal density $\left(F_{H}\right)$, and the calculated length of the ${ }^{3} \mathrm{H}$ labeled segment $\left(\mathrm{L}_{\mathrm{c}}\right)$ are indicated in each diagram. The fragments analyzed were an average length of $6.7 \mu \mathrm{m} .0,{ }^{3} \mathrm{H}$ counts per minute, $O$ normalized counts per minute of ${ }^{14} \mathrm{C}$-labeled normal density DNA. Density increases from right to left in all diagrams. ${ }^{3} \mathrm{H}$ counts per minute analyzed in each gradient were (a) $14,100 \mathrm{cpm}(\mathrm{A}), 18,200 \mathrm{cpm}$ (B), 36,800 cpm (C), 42,600 cpm (D). 3,600 c.pm of $\left[{ }^{14} \mathrm{C}\right] \mathrm{DNA}$ were run in each tube.

chased for $2 \mathrm{~h}$ in the presence of BUdR. DNA was extracted, sheared to fragments of $6.7-\mu \mathrm{m}$ average length, and centrifuged to equilibrium in $\mathrm{CsCl}$ gradients. Fig. 3 shows that the proportion of ${ }^{3} \mathrm{H}$ label banding at densities greater than that of normal DNA $\left(F_{H}\right)$ decreased with increasing time of labeling. This is as expected because as the length of the ${ }^{3} \mathrm{H}$-labeled segment increased, the proportion of label linked to BUdR-labeled dense DNA would have decreased if all the DNA samples were sheared to the same size.

The values of $L_{c}$ calculated from the data of Fig. 3 were plotted against the time of labeling with $\left[{ }^{3} \mathrm{H}\right] \mathrm{CdR}$. Fig. 4 shows that $L_{c}$ increased linearly with time up to $15 \mathrm{~min}$ of labeling. After $15 \mathrm{~min}$ the rate of increase of $\mathrm{L}_{\mathrm{c}}$ with labeling time decreased dramatically. A similar effect is evident in the data of Painter and Schaeffer (21). A probable explanation for this effect is as follows. A meaningful calculation of $L_{c}$ may be obtained only if active replication forks incorporated $\left[{ }^{3} \mathrm{H}\right] \mathrm{CdR}$ for a defined period and then incorporated BUdR, so that the $\left[{ }^{3} \mathrm{H}\right] \mathrm{DNA}$ would be covalently linked to BUdR-labeled DNA. If a replication fork ceased to function (as a result of replicon fusion) during the $\left[{ }^{3} \mathrm{H}\right] \mathrm{CdR}$ pulse, the label incorporated by that fork

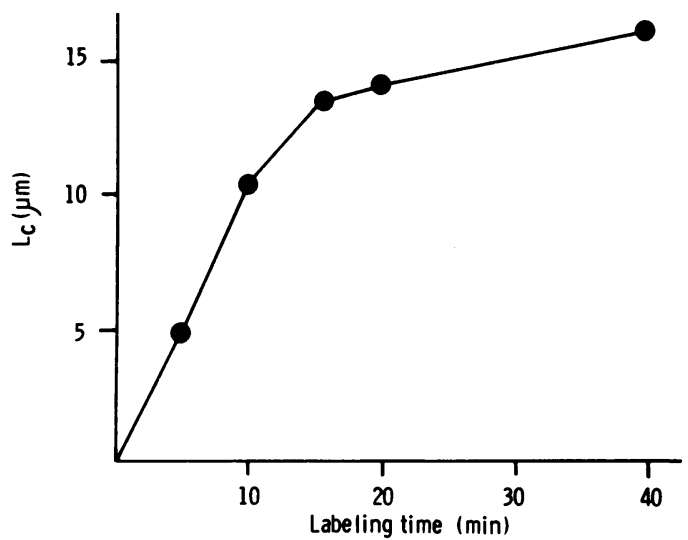

Figure 4 Variation of calculated length of ${ }^{3} \mathrm{H}$-labeled DNA segment $\left(L_{c}\right)$ with time of labeling. Values of $L_{c}$ were derived from the experiments of Fig. 3 . 
would not be linked to BUdR-labeled DNA. The net result would be a decrease in $F_{H}$ and hence an increase in $\mathrm{L}_{\mathrm{c}}$. On the other hand, replication forks that initiated synthesis during the $\left[{ }^{3} \mathrm{H}\right] \mathrm{CdR}$ pulse would contribute BUdR-linked $\left[{ }^{3} \mathrm{H}\right]$ DNA fragments shorter than those synthesized by a fork that was active throughout the labeling period. The effect of mid-pulse initiations would be to decrease $L_{c}$. The calculated value of the fork movement rate would be distorted by both these factors. The degree of distortion would be expected to increase with increasing length of the $\left[{ }^{3} \mathrm{H}\right] \mathrm{CdR}$ pulse. The data of Fig. 4 indicate that the effect of mid-pulse initiations had a greater effect in distorting the fork rate than did replicon fusion. Because a linear rate of increase of $L_{c}$ with time was observed up to $15 \mathrm{~min}$ of labeling, all further experiments were carried out using labeling times of $15 \mathrm{~min}$.

Painter and Schaeffer (21) also observed that for a given labeling time the value of $L_{c}$ increased as $B$ increased. We too have observed that phenomenon. For example, $\mathrm{CsCl}$ gradient centrifugation of DNA labeled with $\left.{ }^{3} \mathrm{H}\right] \mathrm{CdR}$ for 20 min yielded an $\mathrm{L}_{\mathrm{c}}$ value of $14 \mu \mathrm{m}$ when fragments of $6.7 \mu \mathrm{m}$ were analyzed (Fig. 3C). However, when fragments of $13 \mu \mathrm{m}$ were used, $F_{H}$ was 0.295 , yielding a value of $21 \mu \mathrm{m}$ for $\mathrm{L}_{\mathrm{c}}$. This trend was observed consistently in several experiments (e.g., see Table II, experiments 1 and 2). Painter and Schaeffer (21) have shown that their method is limited by the accuracy of estimation of $F_{H}$. The greater the value of $F_{H}$, the greater is its underestimation resulting from overlap of partially heavy DNA into the normal density region. Therefore, the higher the value of $B$, the higher the value of $F_{H}$ and hence the greater the underesti- mation of $F_{H}$. Underestimation of $F_{H}$ would result in an overestimation of $L_{c}$ (see Eq. 1 and 2). It follows that more accurate estimations of $L_{c}$ would be made at lower values of B. However, using fragments of $6.7 \mu \mathrm{m}$ average length, a fork rate close to $1 \mu \mathrm{m} / \mathrm{min}$ was inferred from the first slope of Fig. 4. This value is in close agreement with estimates of fork rates made in a variety of eukaryotic cells using the density-shift technique, velocity sedimentation in sucrose gradients, and autoradiography (2).

The increase in density of BUdR-substituted DNA over that of normal DNA depends on the extent to which BUdR replaced TdR in the DNA. We were concerned that untreated megaloblastic lymphocytes or lymphocytes treated with the deoxyribonucleotide pool-depleting drugs hydroxyurea or methotrexate would incorporate a higher proportion of BUdR than control cells. The effect of this would be to cause a greater increase in density of the BUdR-substituted DNA in cells with depleted deoxythymidine triphosphate pools, resulting in higher values of $\mathrm{F}_{\mathrm{H}}$. Such artefacts would result in lower values of $L_{c}$, and a reduced rate of fork movement would be wrongly inferred. We eliminated this possibility by labeling cells with $2 \mu \mathrm{Ci} / \mathrm{ml}(0.4 \mathrm{nM})\left[{ }^{3} \mathrm{H}\right] \mathrm{TdR}$ in the presence of $20 \mu \mathrm{M}$ BUdR, $1 \mu \mathrm{M}$ FUdR, and $10 \mu \mathrm{M} \mathrm{CdR}$ (i.e., the conditions used during the BUdR chase in our experimental protocol). Vitamin-treated and untreated megaloblastic lymphocytes as well as normal lymphocytes pretreated for $1 \mathrm{~h}$ with $1 \mu \mathrm{M}$ methotrexate of $0.5 \mathrm{mM}$ hydroxyurea were labeled using this procedure. Their DNA was extracted after $2 \mathrm{~h}$ incubation and centrifuged to equilibrium in $\mathrm{CsCl}$ gradients together with ${ }^{14} \mathrm{C}$ normal

TABLE II

Calculation of Rates of Replication Fork Movement in Lymphocytes from Four Patients with Megaloblastic Anemia*

\begin{tabular}{|c|c|c|c|c|c|c|}
\hline Experiment & & Patient & B & $F_{H}$ & $\mathrm{~L}_{\mathrm{c}}$ & $\begin{array}{c}\text { Rate of fork } \\
\text { movement }\end{array}$ \\
\hline & & & $\mu m$ & & $\mu m$ & $\mu \mathrm{m} / \mathrm{min}$ \\
\hline \multirow[t]{4}{*}{1} & \multirow[t]{4}{*}{ A.M. } & Control & 7.1 & 0.233 & 15 & 1.0 \\
\hline & & Control & 12 & 0.364 & 16 & 1.1 \\
\hline & & Megaloblastic & 7.1 & 0.623 & 5.0 & 0.4 \\
\hline & & Megaloblastic & 12 & 0.710 & 7.0 & 0.5 \\
\hline \multirow[t]{4}{*}{2} & \multirow[t]{4}{*}{ B.McI } & Control & 7.1 & 0.262 & 13 & 0.90 \\
\hline & & Control & 12 & 0.316 & 19 & 1.3 \\
\hline & & Megaloblastic & 7.1 & 0.589 & 5.8 & 0.4 \\
\hline & & Megaloblastic & 12 & 0.688 & 7.6 & 0.5 \\
\hline \multirow[t]{2}{*}{3} & \multirow[t]{2}{*}{ M.P. } & Control & 12 & 0.241 & 25 & 1.7 \\
\hline & & Megaloblastic & 12 & 0.358 & 17 & 1.1 \\
\hline \multirow[t]{2}{*}{4} & \multirow[t]{2}{*}{ G.M. } & Control & 7.7 & 0.257 & 15 & 1.0 \\
\hline & & Megaloblastic & 7.7 & 0.281 & 14 & 0.9 \\
\hline
\end{tabular}

* The time of labeling with $\left[{ }^{3} \mathrm{H}\right] \mathrm{CdR}$ was 15 min in all experiments. 
density DNA. In all four samples an identical shift of 7.5 fractions was observed between the peaks of normal density DNA and BUdR-substituted material, corresponding to an increase in $d$ of $0.042 \mathrm{~g} / \mathrm{ml}$. We concluded that the effect of the $1 \mu \mathrm{M}$ FUdR present during BUdR labeling reduced the cellular thymidine nucleotide pools so effectively that any differences in degree of substitution with BUdR that would have been caused by megaloblastic anemia or treatment with pool-depleting drugs were abolished.

Calculation of rates of fork movement in megaloblastic and control lymphocytes. Fig. 5 summarizes the data from an experiment in which rates of replication fork movement were compared in megaloblastic lymphocytes and in corresponding control cells obtained by the addition of folinic acid to the culture medium. The cells were labeled for $15 \mathrm{~min}$ with $\left[{ }^{3} \mathrm{H}\right]-$ $\mathrm{CdR}$, chased for $2 \mathrm{~h}$ in the presence of BUdR, and the DNA extracted from each set of cells. Aliquots of each DNA sample were sheared to either $7.1 \mu \mathrm{m}$ (Fig. 5A and C) or $12 \mu \mathrm{m}$ (Fig. 5B and D) and analyzed on $\mathrm{CsCl}$ gradients. The value of $\mathrm{F}_{H}$ was markedly greater in the megaloblastic lymphocytes than in the controls, for a given value of $B$ (compare Fig. 5A and $C$ and Fig. 5B and $D$ ). The values of $L_{c}$ derived from this study are summarized in experiment 1 of Table II. The corresponding rates of fork movement are also presented. It is clear that the velocity of fork movement in the megaloblastic lymphocytes was $\sim 40 \%$ of that in the controls. A reduced fork rate was observed in three further experiments using lymphocytes from three different patients (Table II, experiments 2-4). In experiment 4 , the difference was much less marked than in the other experiments, a reduction in rate of only $8 \%$ having been observed.

The data of both experiments 1 and 2 of Table II demonstrate that the greater the length of the DNA pieces analyzed, the higher the calculated rate of fork movement. A possible reason for this effect was discussed above. However, in both experiments 1 and 2 of Table II the ratio of fork rates (rate in megaloblastic: rate in control) was $\sim 0.4$ regardless of the size of the DNA fragments.

Similar experiments were carried out using lymphocytes that had been pretreated for $1 \mathrm{~h}$ with either $1 \mu \mathrm{M}$ methotrexate or $0.5 \mathrm{mM}$ hydroxyurea. The extracted

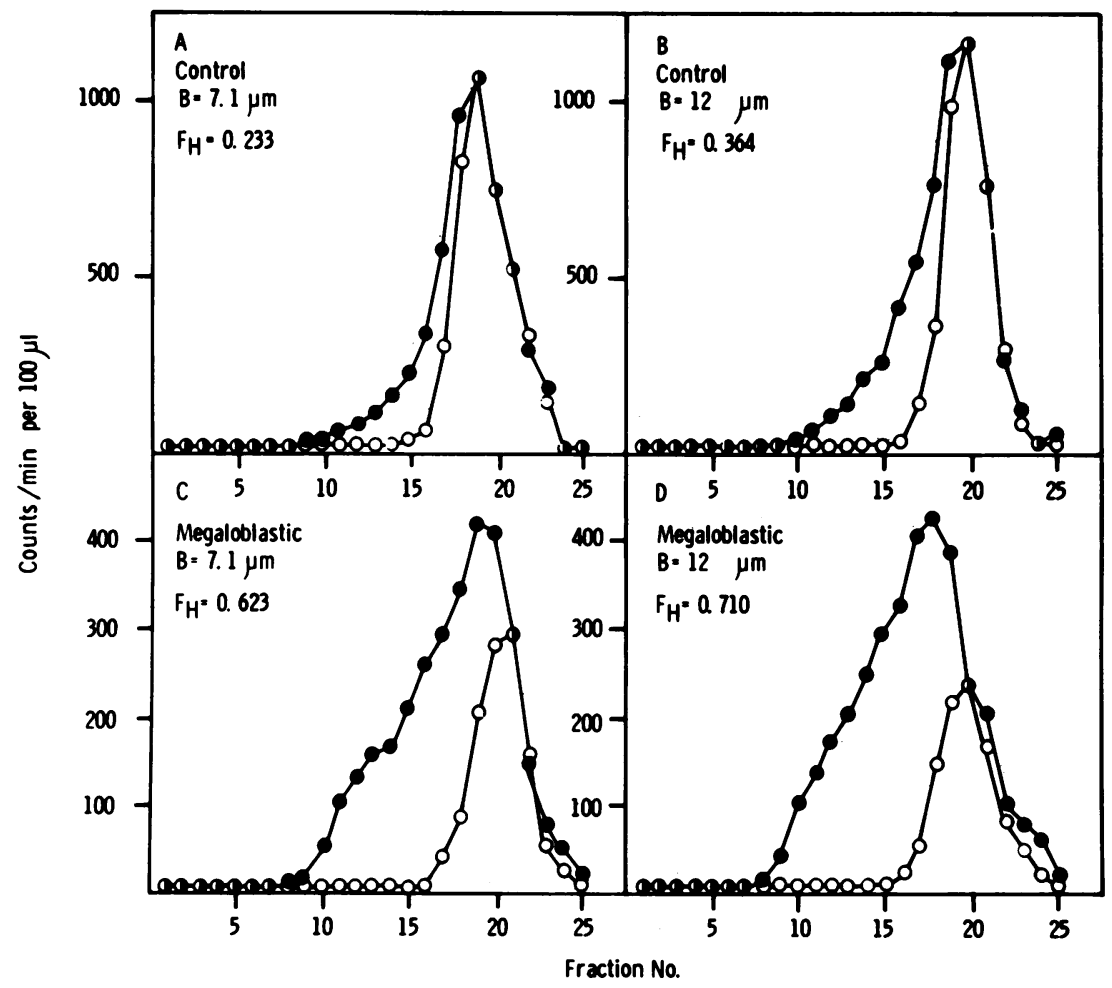

FIGURE $5 \mathrm{CsCl}$ density gradient profiles of DNA labeled for $15 \mathrm{~min}$ with $\left[{ }^{3} \mathrm{H}\right] \mathrm{CdR}$ and chased for $2 \mathrm{~h}$ in the presence of BUdR. (A and B) vitamin-treated control lymphocytes; (C and D) untreated lymphocytes (from patient A.M.). Size of the DNA analyzed (B) and the fraction of ${ }^{3} \mathrm{H}$ label banding at greater than normal density $\left(\mathrm{F}_{\mathrm{H}}\right)$ are indicated in each panel. $0,{ }^{3} \mathrm{H}$ counts per minute, $O$, normalized ${ }^{14} \mathrm{C}$ counts per minute. Amounts of radioactivity analyzed were: $A$ and $\mathrm{B}, 36,000{ }^{3} \mathrm{H} \mathrm{cpm}$ and $4,000{ }^{14} \mathrm{C} \mathrm{cpm}$; $\mathrm{C}$ and $\mathrm{D}, 23,000{ }^{3} \mathrm{H} \mathrm{cpm}$ and $1,500{ }^{14} \mathrm{C} \mathrm{cpm}$. 
DNA was sheared to fragments of $6.8 \mu \mathrm{m}$ and centrifuged in $\mathrm{CsCl}$ as before. A very large proportion $(>85 \%)$ of the ${ }^{3} \mathrm{H}$ label was recovered in DNA banding at densities greater than that of normal DNA. Meaningful calculations of the fork rate were not possible at such high values of $F_{H}$. However, the data indicate qualitatively that treatment of lymphocytes with either of these drugs profoundly reduced the replication fork rate.

\section{DISCUSSION}

We have used PHA-stimulated lymphocytes from patients with megaloblastic anemia to study the defects in DNA synthesis associated with this syndrome. In each experiment, controls were obtained by adding folinic acid to the culture medium. Folinic acid alone has been found to correct the abnormal deoxyuridine supression test $(31,32)$ and abnormalities of DNA chain growth as detected by alkaline sucrose gradient centrifugation (19) in cells of patients with deficiencies in either vitamin $B_{12}$ or folate. This is explicable on the basis of the methyl tetrahydrofolate trap hypothesis $(11,33)$ because folinic acid bypasses the vitamin $B_{12^{-}}$ dependent methionine synthetase reaction thought to be required for the conversion of dietary folate (5-methyl tetrahydrofolate) into a form available for intracellular metabolism. We have also established that the biochemical lesions expressed by megaloblastic lymphocytes under our culture conditions are a feature of the cells themselves and do not result from culturing them in the absence of folic acid and thymine. When cells from a normal donor were cultured in the medium without thymine and folic acid and in the presence of dialyzed serum, they did not express megaloblastic abnormalities as detected by the deoxyuridine supression test $(31,32)$ or by alkaline sucrose gradient sedimentation (19).

Using chromatograpy on BND cellulose to separate fully double-stranded DNA from partially single-stranded material (20), we have demonstrated that no gross accumulation of single-stranded DNA regions can be detected in the DNA of megaloblastic lymphocytes (Fig. 1). Approximately $25 \%$ of the DNA of both megaloblastic and control lymphocytes eluted in the partially single-stranded fraction. Henson (30) has found that a similar proportion of the DNA of Chinese hamster ovary cells was partially single-stranded in the $G_{1}$ phase. She concluded that these single-stranded regions were not related to replication. DNA synthesized by normal lymphocytes in the presence of the deoxyribonucleotide pool-depleting drugs methotrexate $(20 \mu \mathrm{M})$ or hydroxyurea $(0.5 \mathrm{mM})$ also failed to show an accumulation of partially single-stranded DNA regions (unpublished observations).

DNA of lymphocytes pulse-labeled with $\left[{ }^{3} \mathrm{H}\right]-$ thymidine for 5 min contained $\sim 80 \%$ of the label in DNA eluting in the partially single-stranded fraction (Fig. 2). After chasing in unlabeled medium, the label shifted progressively into the fully double-stranded fraction. By $1-2 \mathrm{~h}$ of chase the proportion of label in partially single-stranded DNA in normal lymphocytes (Fig. 2B and $C$ ) and in megaloblastic lymphocytes treated with folinic acid (Fig. 2A) fell to a value similar to that of uniformly labeled DNA. In contrast, the shift of pulse label to the fully double-stranded fraction was considerably delayed in untreated megaloblastic lymphocytes (Fig. 2A), or in lymphocytes treated with methotrexate (Fig. 2B) or hydroxyurea (Fig. 2C). Treatment of 5 min pulse-labeled DNA with a nuclease specific for single-stranded nucleic acids resulted in a considerable shift of label from the partially singlestranded to the double-stranded fraction with negligible solubilization of the label. This experiment was consistent with the presence of short gaps in the newly synthesized DNA strand resulting in exposed singlestranded regions in the unlabeled template DNA near the replication fork, in agreement with current concepts of DNA replication $(2,10)$. The above pulse-chase experiments led us to the tentative hypothesis that the rate of transfer of pulse label to the double-stranded DNA fraction reflected the rate of replication fork movement, because the partially single-stranded fork region would need to have moved out of the DNA fragment containing pulse label before the label appeared in the double-stranded DNA fraction. This hypothesis is supported by the fact that sonication of pulse-labeled DNA reduced the proportion of partially singlestranded label from 80 to $33 \%$ (Fig. 2D). This would be expected since sonication would be expected to separate much of the label from the fork region. The experiments detailed in Fig. 2 suggest that the rate of replication fork movement was reduced in megaloblastic lymphocytes and in cells treated with methotrexate or hydroxyurea.

Direct measurement of replication fork rates was attempted using the density shift technique of Painter and Schaeffer (21). Their method was modified (detailed in Methods) to avoid possible artifacts resulting from labeling with $\left[{ }^{3} \mathrm{H}\right]$ thymidine. Experiments carried out using lymphocytes from four different patients demonstrated clearly that the rate of replication fork movement was reduced in megaloblastic lymphocytes compared with lymphocytes treated with folinic acid (Fig. 5, Table II). Data from cells treated with methotrexate or hydroxyurea indicated qualitatively that the fork rates were greatly reduced. In a previous study (19) we used alkaline sucrose density gradient sedimentation to demonstrate that the maturation of subreplicon-sized DNA to chromosomal DNA was reduced in megaloblastic anemia. On the basis of the present studies, we can infer that this results from the reduced rate of replication fork movement, because 
a subreplicon-sized nascent DNA molecule must increase in size by fork movement before it can be joined to the nascent strand of the neighboring replication unit.

The interpretation of our results could be complicated by the observation that PHA-stimulated lymphocytes "excrete" a proportion of the DNA synthesized in culture $(34,35)$. However, recent studies have shown that incorporation of $\left[{ }^{3} \mathrm{H}\right]$ thymidine by these cells was due exclusively to semiconservative DNA replication, and that the excretion of DNA by lymphocytes was a result of cell death $(36,37)$. Furthermore, Scudiero et al. (38) demonstrated that repair DNA synthesis does not involve the transient formation of single-stranded regions. For the reason that pulselabeled DNA in our studies behaved as partially singlestranded material (Fig. 2), it is unlikely that a significant proportion of the label incorporated represented repair synthesis.

The biochemical link between the lesions in DNA synthesis described above and elsewhere (19) and the vitamin deficiency states that result in megaloblastic anemia is not completely clear. Application of the deoxyuridine suppression test has demonstrated a marked reduction in the rate of de novo biosynthesis of the DNA precursor deoxythymidine triphosphate in megaloblastic anemia $(31,32)$, probably as a consequence of impaired one-carbon transfer reactions resulting from a deficiency of folate or of vitamin $B_{12}$ (11). This interpretation is supported by the fact that both methotrexate and hydroxyurea, drugs that interfere with DNA precursor synthesis by quite distinct mechansims $(39,40)$, result in lesions in DNA synthesis very similar to those seen in megaloblastic anemia (this paper, and 19). These agents are also known to cause megaloblastic anemia in vivo. Because the rate of replication fork movement is also reduced by the protein synthesis inhibitors cycloheximide (41) and puromycin (42), the possibility that the lesions in DNA synthesis associated with megaloblastic anemia result from a less specific disturbance of cellular metabolism cannot be ruled out. However, it is well known that RNA and protein synthesis are relatively intact in megaloblasts compared with DNA synthesis (11).

Although treatment with methotrexate has been shown to reduce the dTTP pools (43-45), and hydroxyurea causes a drop in dATP levels (45), no depletion in the dTTP pool has been observed in either bone marrow cells or PHA-stimulated lymphocytes from patients with megaloblastic anemia. This apparent paradox may find its resolution if a functional compartmentalization of deoxyribonucleotide pools exists in eukaryotic cells. Reddy and Matthews (46) have published convincing evidence that a kinetically coupled complex of enzymes located near the replication fork of the coliphage $\mathrm{T} 4$ produces a high local con- centration of DNA precursors. There is evidence that the RNA precursor pools in eukaryotic cells are compartmentalized (47). If a similar situation applies to deoxyribonucleotide pools, it is plausible that variations in small, highly concentrated pools located near the replication forks will be obscured by larger but less concentrated pools that are located in the remainder of the cell and do not serve as precursors for genomic replication. Experiments to determine whether functional compartmentalization exists in eukaryotic cells are currently in progress.

\section{ACKNOWLEDGMENT}

We would like to thank the Medical Research Council of Great Britain for financial support.

\section{REFERENCES}

1. Huberman, J. A., and A. D. Riggs. 1968. On the mechanism of DNA replication in mammalian chromosomes. J. Mol. Biol. 32: 327-341.

2. Edenburg, H. J., and J. A. Huberman. 1975. Eukaryotic chromosome replication. Annu. Rev. Genet. 9: 245-384.

3. Nuzzo, F., A. Brega, and A. Falaschi. 1970. DNA replication in mammalian cells. I. The size of the newly synthesized helices. Proc. Natl. Acad. Sci. U. S. A. 65: 1017-1024.

4. Huberman, J. A., and H. Horwitz. 1973. Discontinuous DNA synthesis in mammalian cells. Cold Spring Harbor Symp. Quant. Biol. 38: 233-238.

5. Friedman, C. A., K. W. Kohn, and L. C. Erickson. 1975. DNA chain growth during replication of asynchronous $\mathrm{L}$ 1210 cells. Alkaline sedimentation studies. Biochem. J. 14: 4018-4023.

6. Perlman, D., and J. A. Huberman. 1977. Asymmetric Okazaki piece synthesis during replication of Simian virus 40 DNA in vivo. Cell. 12: 1029-1043.

7. Fox, R. M., J. Mendelsohn, E. Barbosa, and M. Goulian. 1973. RNA in nascent DNA from cultured human lymphocytes. Nature (Lond.). 245: 234-237.

8. Eliasson, R., and P. Reichard. 1978. Primase initiates Okazaki pieces during polyoma DNA synthesis. Nature (Lond.). 272: 184-185.

9. Eliasson, R., and P. Reichard. 1978. Replication of polyoma DNA in isolated nuclei. Synthesis and distribution of initiator RNA. J. Biol. Chem. 253: 7469-7475.

10. Alberts, B., and R. Sternglanz. 1977. Recent excitement in the DNA replication problem. Nature (Lond.). 269: $655-661$

11. Hoffbrand, A. V., K. Ganeshaguru, J. W. L. Hooton, and E. Tripp. 1976. Megaloblastic anaemia. Initiation of DNA synthesis in excess of DNA chain elongation as the underlying mechanism. Clin. Haematol. 5: 727-745.

12. Magnusson, G. 1973. Hydroxyurea-induced accumulation of short fragments during polyoma DNA replication. I. Characterization of fragments. J. Virol. 12: 600-608.

13. Laipis, P. J., and A. J. Levine. 1973. DNA replication in SV40 infected cells. IX. The inhibition of a gapfilling step during discontinuous synthesis of SV40 DNA. Virology. 56: 580-594.

14. Martin, R. F., I. Radford, and M. Pardee. 1977. Accumulation of short DNA fragments in hydroxyurea treated mouse L cells. Biochem. Biophys. Res. Commun. 74: $9-15$. 
15. Salzman, N. P., and M. M. Thoren. 1973. Inhibition in the joining of DNA intermediate to growing simian virus 40 chains. J. Virol. 11: 721-729.

16. Chan, A. C., and I. G. Walker. 1975. DNA synthesis in L-cells in the presence of 5-fluorodeoxyuridine. Biochim. Biophys. Acta. 395: 422-432.

17. Das, K. C., and A. V. Hoffbrand. 1970. Studies of folate uptake by phytohaemagglutinin-stimulated lymphocytes. Br. J. Haematol. 19: 203-221.

18. Das, K. C., and A. V. Hoffbrand. 1970. Lymphocyte transformation in megaloblastic anaemia: morphology and DNA synthesis. Br. J. Haematol. 19: 459-468.

19. Wickremasinghe, R. G., and A. V. Hoffbrand. 1979. Defective DNA synthesis in megaloblastic anaemia: studies employing velocity sedimentation in alkaline sucrose density gradients. Biochim. Biophys. Acta. 563: 46-58.

20. Iyer, V. N., and W. D. Rupp. 1971. Usefulness of benzoylated naphthoylated DEAE-cellulose to distinguish and fractionate double-stranded DNA bearing different extents of single-stranded regions. Biochim. Biophys. Acta. 228: 117-126.

21. Painter, R. B., and A. W. Schaeffer. 1969. Rate of synthesis along replicons of different kinds of mammalian cells. J. Mol. Biol. 45: 467-479.

22. Böyum, A. 1968. Isolation of leucocytes from human blood. Further observations. Scand. J. Clin. Lab. Invest. 21(Suppl.): 97.

23. Fakan, S., G. N. Turner, J. S. Pagano, and R. Hancock. 1972. Site of replication of chromosomal DNA in eukaryotic cell. Proc. Natl. Acad.Sci. U.S. A. 69: 2300-2305.

24. Linn, S., and I. R. Lehman. 1975. An endonuclease from Neurospora crassa specific for polynucleotides lacking an orderly structure. J. Biol. Chem. 240: 1294-1299.

25. Bollum, F. J. 1968. Filter paper disk techniques for assaying radioactive macromolecules. Methods Enzymol. 21B: 591-611.

26. Funding, L., and J. Steensgaard. 1973. A simple manual method for the calculation of equivalent sedimentation coefficients from rate-zonal centrifugation experiments. MSE Application Information, A8/6/73. MSE Scientific Instruments, Manor Royal, Crawley, Sussex.

27. Studier, F. W. 1965. Sedimentation studies of the size and shape of DNA. J. Mol. Biol. 11: 373-390.

28. Reichard, P. 1978. From deoxynucleotides to DNA synthesis. Fed. Proc. 37: 9-14.

29. Hayton, G. J., C. K. Pearson, and H. M. Keir. 1973. The effect of an exonuclease specific for single-stranded DNA on the properties of newly synthesized DNA from BHK21/C13 cells. Biochem. Soc. Trans. 1: 452-455.

30. Henson, $P$. 1978. The presence of single stranded regions in mammalian DNA. J. Mol. Biol. 119: 487-506.

31. Wickremasinghe, S. N., and J. E. Longland. 1974. Assessment of deoxyuridine suppression test in diagnosis of vitamin $\mathrm{B}_{12}$ or folate deficiency. Br. Med. J. 3: $148-150$.
32. Ganeshaguru, K., and A. V. Hoffbrand. 1978. The effect of deoxyuridine, vitamin $B_{12}$, folate, and alcohol on the uptake of thymidine and on the deoxynucleoside triphosphate concentrations in normal and megaloblastic cells. Br. J. Haematol. 40: 29-41.

33. Herbert, V., and R. Zalusky. 1962. Interrelationship of vitamin $B_{12}$ and folic acid metabolism: folic acid clearance studies. J. Clin. Invest. 41: 1263-1276.

34. Rogers, J. C., D. Boldt, S. Kornfeld, S. A. Skinner, and C. R. Valeri. 1972. Excretion of deoxyribonucleic acid by lymphocytes stimulated with phytohaemagglutinin or antigen. Proc. Natl. Acad. Sci. U. S. A. 69: 1685-1689.

35. Sarma, D. S. R., and J. Zubroff. 1973. Synthesis and fragmentation of DNA in phytohaemagglutinin-stimulated human peripheral blood lymphocytes. Immunol. Commun. 2: 277-285.

36. Bernheim, J. L., R. E. Dorian, and J. Mendelsohn. 1978. DNA synthesis and proliferation of human lymphocytes in vitro. I. Cell kinetics of response to phytohaemagglutinin. J. Immunol. 120: 955-962.

37. Bernheim, J. L., and J. Mendelsohn. 1978. DNA synthesis and proliferation of human lymphocytes in vitro. II. Characterization of the DNA newly synthesized after phytohaemagglutinin stimulation. J. Immunol. 120: 963970 .

38. Scudiero, D., E. Henderson, A. Norin, and B. Strauss. 1975. The measurement of chemically-induced DNA repair synthesis in human cells by BND-cellulose chromatography. Mutat. Res. 29: 473-488.

39. Werkheiser, W. C. 1961. Special binding of 4-aminofolic acid analogues by folic acid reductase. J. Biol. Chem. 236: 888-893.

40. Reichard, P. 1972. Control of deoxyribonucleotide synthesis in vitro and in vivo. Adv. Enzyme Regul. 10: 3-16.

41. Gautschi, J. R., and R. M. Kern. 1973. DNA replication in mammalian cells in the presence of cycloheximide. Exp. Cell Res. 80: 15-26.

42. Gautschi, J. R. 1974. Effect of puromycin on DNA chain elongation in mammalian cells.J. Mol. Biol. 84: 223-229.

43. Hoffbrand, A. V., and E. Tripp. 1972. Unbalanced deoxyribonucleotide synthesis caused by methotrexate. $\mathrm{Br}$. Med. J. 2: 140-142.

44. Fridland, A. 1973. Effect of methotrexate on deoxyribonucleotide pools and DNA synthesis in human lymphocytic cells. Cancer Res. 34: 1883-1888.

45. Ganeshaguru, K. 1977. Ph.D. thesis, University of London. Deoxyribonucleoside triphosphate concentrations in human cells: changes caused by drugs and disease.

46. Reddy, G. P. V., and C. K. Matthews. 1978. Functional compartmentation of DNA precursors in T4 phageinfected bacteria. J. Biol. Chem. 253: 3461-3467.

47. Khym, J. X., M. H. Jones, W. H. Lee, J. D. Regan, and E. Volkin. 1978. On the question of compartmentalization of the nucleotide pool. J. Biol. Chem. 253: 8741-8746. 